\title{
Physiological energetics of mussel larvae (Mytilus edulis). IV. Efficiencies
}

\author{
Martin Sprung* \\ Biologische Anstalt Helgoland, Meeresstation, D-2192 Helgoland, Federal Republic of Germany
}

\begin{abstract}
Assimilation efficiency, gross growth efficiency $\mathrm{K}_{1}$ and net growth efficiency $\mathrm{K}_{2}$ have been estimated for marine mussel larvae (Mytilus edulis L.). These calculations are based on data of growth, food uptake and respiration determined for distinct larval sizes at standard conditions: 1, 2, 5, 10,20 and 40 Isochrysis cells $\mu \mathrm{I}^{-1}$ and 6,12 and $18^{\circ} \mathrm{C}$. Assimilation efficiency ranged between 20 and $50 \%$ and tended to be highest at food concentrations below 5 cells $\mu l^{-1}$. Gross growth efficiency had maximum values between 25 and $40 \%$, net growth efficiency between 60 and $70 \%$.
\end{abstract}

\section{INTRODUCTION}

Dealing with the physiology of an organism in terms of an energy budget accounts for the systems nature of energetic processes in the animal. It takes the view that energy is shifted between certain compartments. These compartments are e.g. food uptake, faecal losses, growth and respiration. Due to the systems nature no compartment can be changed without affecting the others in some way. Energy budgets describe the content of these compartments, efficiencies (as those calculated in this paper) the energy exchange between them.

This is a quite modern view taken in physiological ecology. It has been greatly influenced by the progress made in systems ecology. Energy flow in an organism may provide basic information on energy flow through the ecosystem (e.g. Jørgensen, 1983). Hence most budget data are of recent origin.

For mussel larvae efficiencies of energetic processes have been estimated by Jørgensen (1952, 1981), Bayne (1976) and Jespersen and Olsen (1982). Basic data of the efficiencies calculated here have been described in 3 previous papers on growth, food uptake and respiration of mussel larvae (Sprung, 1984a, b, c).

\footnotetext{
- Present address: Physiological Ecology Section, Department of Zoology, University of Köln, Weyertal 119, D-5000 Köln 41, Federal Republic of Germany

\section{MATERIALS AND METHODS}

Data on growth, food uptake and respiration have been estimated for larvae of various sizes at 6,12 and $18^{\circ} \mathrm{C}$. With respect to growth and food uptake, standard food conditions of the flagellate Isochrysis galbana have also been established $(1,2,5,10,20$ and 40 cells $\mu \mathrm{l}^{-1}$ ).

Data have been interpolated by regression lines to standard larval sizes: $120 \mu \mathrm{m}$ (corresponding to the Dshaped stage), 150, 200, $250 \mu \mathrm{m}$ shell length. They have been converted to the units $\mu$ Joule and hour.

With these data the following efficiencies have been estimated:

(1) Assimilation efficiency: it was calculated by

$$
\frac{\text { Respiration rate }+ \text { Growth rate }}{\text { Ingestion rate }} \times 100
$$

It denotes the part of the food ingested which is assimilated. Assimilation in this context has been defined as the sum of respiration and growth (Crisp, 1971).

(2) Gross growth efficiency: it was calculated by

$$
\frac{\text { Growth rate }}{\text { Ingestion rate }} \times 100
$$

It denotes the part of the food ingested which is converted to growth.

(3) Net growth efficiency: it was calculated by

$$
\frac{\text { Growth rate }}{\text { Growth rate }+ \text { Respiration rate }} \times 100
$$


Table 1. Mytilus edulis, larvae. Budget data; R: respiration rate; $I$ : ingestion rate; G: growth rate; units: $\mu J_{0}$ (le $h^{-1}$ (Data from Sprung, 1984a, b, c)

\begin{tabular}{|c|c|c|c|c|c|c|c|c|c|c|c|c|c|}
\hline \multirow{2}{*}{$\begin{array}{l}\text { Tem- } \\
\text { pera- } \\
\text { ture }\end{array}$} & \multirow{2}{*}{$\begin{array}{c}\text { Food } \\
\text { concentration } \\
(\text { Isochrysis } \\
\left.\text { cells } \mu \mathrm{I}^{-1}\right)\end{array}$} & \multicolumn{3}{|c|}{$120 \mu \mathrm{m}$ shell length } & \multicolumn{3}{|c|}{$150 \mu \mathrm{m}$ shell length } & \multicolumn{3}{|c|}{$200 \mu \mathrm{m}$ shell length } & \multicolumn{3}{|c|}{$250 \mu \mathrm{m}$ shell length } \\
\hline & & $\mathrm{R}$ & I & G & $\mathrm{R}$ & I & $G$ & $\mathrm{R}$ & I & G & R & $I$ & G \\
\hline \multirow{6}{*}{$6^{\circ} \mathrm{C}$} & 1 & 1.1 & 2.8 & 1.2 & 2.1 & 4.6 & 1.8 & 4.6 & 8.7 & 2.5 & - & - & - \\
\hline & 2 & 1.1 & 5.1 & 1.9 & 2.1 & 8.6 & 3.3 & 4.6 & 16.9 & 6.3 & - & - & - \\
\hline & 5 & 1.1 & 8.4 & 1.9 & 2.1 & 13.1 & 3.3 & 4.6 & 23.3 & 7.4 & 8.6 & 34.6 & 11.6 \\
\hline & 10 & 1.1 & 9.9 & 2.8 & 2.1 & 15.6 & 4.5 & 4.6 & 27.8 & 8.0 & 8.6 & 43.7 & 12.5 \\
\hline & 20 & 1.1 & 12.2 & 3.1 & 2.1 & 18.3 & 4.8 & 4.6 & 30.8 & 8.6 & 8.6 & 46.3 & 13.5 \\
\hline & 40 & 1.1 & 11.1 & 3.1 & 2.1 & 18.2 & 4.9 & 4.6 & 34.4 & 8.8 & 8.6 & 56.3 & 13.8 \\
\hline \multirow{6}{*}{$12^{\circ} \mathrm{C}$} & 1 & 2.9 & 6.2 & 1.1 & 4.7 & 11.0 & - & - & - & - & - & - & - \\
\hline & 2 & 2.9 & 12.2 & 2.6 & 4.7 & 21.2 & 4.1 & 8.9 & 43.1 & 7.4 & 14.4 & 74.6 & 11.6 \\
\hline & 5 & 2.9 & 23.0 & 4.3 & 4.7 & 42.2 & 6.7 & 8.9 & 92.0 & 12.0 & 14.4 & 168 & 18.9 \\
\hline & 10 & 2.9 & 24.4 & 7.3 & $4.7^{\circ}$ & 44.8 & 11.4 & 8.9 & 98.0 & 20.5 & 14.4 & 180 & 32.2 \\
\hline & 20 & 2.9 & 24.9 & 7.0 & 4.7 & 44.9 & 11.1 & 8.9 & 96.0 & 19.8 & 14.4 & 173 & 31.0 \\
\hline & 40 & 2.9 & 23.7 & 6.2 & 4.7 & 41.2 & 9.7 & 8.9 & 84.1 & 17.3 & 14.4 & 146 & 27.1 \\
\hline \multirow{6}{*}{$18^{\circ} \mathrm{C}$} & 1 & 6.8 & 7.9 & 3.7 & 10.3 & 11.7 & 5.8 & - & - & - & - & - & - \\
\hline & 2 & 6.8 & 11.6 & 3.8 & 10.3 & 19.0 & 6.0 & 17.4 & 35.8 & 10.7 & 26.1 & 58.5 & 16.8 \\
\hline & 5 & 6.8 & 29.2 & 6.2 & 10.3 & 49.2 & 9.7 & 17.4 & 96.5 & 17.4 & 26.1 & 163 & 27.3 \\
\hline & 10 & 6.8 & 27.9 & 9.3 & 10.3 & 50.7 & 14.5 & 17.4 & 109 & 26.0 & 26.1 & 198 & 40.8 \\
\hline & 20 & 6.8 & 22.9 & 10.3 & 10.3 & 47.1 & 16.1 & 17.4 & 120 & 28.8 & 26.1 & 244 & 45.2 \\
\hline & 40 & 6.8 & 19.8 & 10.6 & 10.3 & 43.8 & 16.7 & 17.4 & 122 & 29.9 & 26.1 & 270 & 46.9 \\
\hline
\end{tabular}

It denotes the part of the food assimilated which is converted to growth.

\section{RESULTS}

Budget data have been compiled in Table 1 and the efficiencies calculated in Table 2. Data on assimilation efficiency, gross growth efficiency and net growth efficiency have been graphically represented in Fig. 1.

At food concentrations between 5 and 40 cells $\mu \mathrm{I}^{-1}$, assimilation efficiency ranges between 20 and $50 \%$ of the food ingested. A uniform trend cannot be outlined within these 4 food concentrations tested.

At $6^{\circ} \mathrm{C}$ the assimilation efficiencies calculated show a slightly increasing tendency with larval size, at $12^{\circ} \mathrm{C}$ a slightly decreasing tendency, and at $18^{\circ} \mathrm{C}$ a clearly decreasing tendency. At a food concentration of 2 cells $\mu \mathrm{l}^{-1}$ an elevated assimilation efficiency was estimated.

Gross growth efficiency $\mathrm{K}_{1}$ ranges between 15 and $40 \%$ of the food ingested. Among the food concentrations tested no distinct trend can be outlined. At $6^{\circ} \mathrm{C}$ the $\mathrm{K}_{1}$-values are obviously not influenced by larval size, at $12^{\circ} \mathrm{C}$ gross growth efficiency decreases with larval size. This decrease is even more pronounced at $18^{\circ} \mathrm{C}$.

Maximum values of the net growth efficiency $\mathrm{K}_{2}$ range between 60 and $70 \%$ of the assimilated ration.
At $6^{\circ} \mathrm{C}$ net growth efficiency decreases slightly with larval size, at $12^{\circ} \mathrm{C}$ it stays more or less constant and at $18^{\circ} \mathrm{C} \mathrm{K}_{2}$-values increase with larval size. Net growth efficiencies reach a plateau at 10 cells $\mu l^{-1}$ and remain fairly constant up to 40 cells $\mu l^{-1}$.

A general trend which can be attributed to the temperature cannot be noted with any of these 3 efficiencies calculated.

\section{DISCUSSION}

The data compiled in Table 1 do not account for the whole energy budget of mussel larvae. The complex involved in exchange of dissolved substances (e.g. uptake as food, release as excretory products or due to leakage) has been omitted. Nevertheless the efficiencies which could be calculated demonstrate some interesting phenomena. They describe the interaction between the animal and its food under a given environmental condition. Consequently, they are not constant. This fact is most evident for the assimilation efficiency.

\section{Assimilation efficiency}

Corner and Davies (1971) have pointed out that the assimilation efficiency is greatly influenced by the quality of the food, e.g. its chemical and mechanical properties such as particle size. Furthermore different 

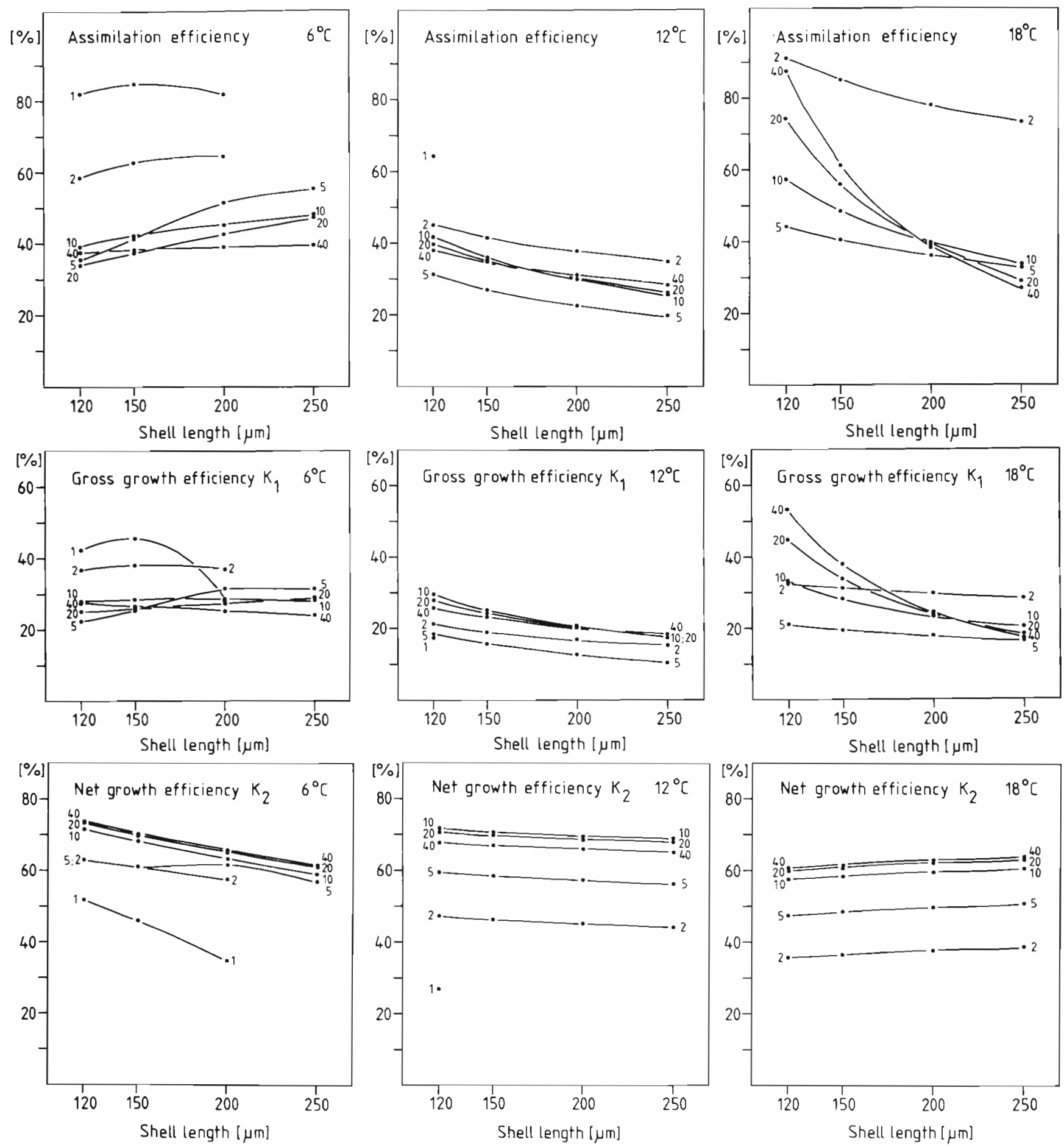

Fig. 1. Mytilus edulis, larvae. Efficiencies at various food concentrations (Isochrysis cells $\mu l^{-1}$ ) and temperatures; data from Table 2 ; curves fitted by eye

components of the food are not assimilated with the same efficiency.

In the recent literature (e.g. Bayne, 1984) it is distinguished between absorption and assimilation efficiency. Absorption is then defined as the passage of substance through the walls of the intestine. Absorption efficiency has been frequently estimated by means of the Conover rate (Conover, 1966). In contrast to the assimilation efficiency, absorption efficiency includes also the energy of exudates. 
Table 2. Mytilus edulis, larvae. Assimilation efficiencies (AE), gross growth efficiencies $\left(\mathrm{K}_{1}\right)$ and net growth efficiencies $\left(\mathrm{K}_{2}\right)$ calculated from Table 1

\begin{tabular}{|c|c|c|c|c|c|c|c|c|c|c|c|c|c|}
\hline \multirow{2}{*}{$\begin{array}{l}\text { Tem- } \\
\text { pera- } \\
\text { ture }\end{array}$} & \multirow{2}{*}{$\begin{array}{c}\text { Food } \\
\text { concentration } \\
(\text { Isochrysis } \\
\left.\text { cells } \mu \mathrm{I}^{-1}\right)\end{array}$} & \multicolumn{3}{|c|}{$120 \mu \mathrm{m}$ shell length } & \multicolumn{3}{|c|}{$150 \mu \mathrm{m}$ shell length } & \multicolumn{3}{|c|}{$200 \mu \mathrm{m}$ shell length } & \multicolumn{3}{|c|}{$250 \mu \mathrm{m}$ shell length } \\
\hline & & $\mathrm{AE}$ & $\mathrm{K}_{1}$ & $\mathrm{~K}_{2}$ & $\mathrm{AE}$ & $\mathrm{K}_{1}$ & $\mathrm{~K}_{2}$ & $A E$ & $K_{1}$ & $\mathrm{~K}_{2}$ & $\mathrm{AE}$ & $\mathrm{K}_{1}$ & $\mathrm{~K}_{2}$ \\
\hline \multirow{6}{*}{$6^{\circ} \mathrm{C}$} & 1 & 82.1 & 42.9 & 52.1 & 84.8 & 39.1 & 46.1 & 81.6 & 28.7 & 35.2 & - & - & - \\
\hline & 2 & 58.8 & 37.2 & 63.3 & 62.8 & 38.4 & 61.1 & 64.5 & 37.3 & 57.8 & - & - & - \\
\hline & 5 & 35.7 & 22.6 & 63.3 & 41.2 & 25.2 & 61.1 & 51.5 & 31.8 & 61.7 & 55.5 & 31.9 & 57.4 \\
\hline & 10 & 39.4 & 28.3 & 71.8 & 42.3 & 28.8 & 68.2 & 45.3 & 28.8 & 63.5 & 48.3 & 28.6 & 59.2 \\
\hline & 20 & 34.4 & 25.4 & 73.8 & 37.7 & 26.2 & 69.6 & 42.9 & 27.9 & 65.2 & 47.7 & 29.2 & 61.1 \\
\hline & 40 & 37.8 & 27.9 & 73.8 & 38.5 & 26.9 & 70.0 & 39.0 & 25.6 & 65.7 & 39.8 & 24.5 & 61.6 \\
\hline \multirow{6}{*}{$12^{\circ} \mathrm{C}$} & 1 & 64.5 & 17.7 & 27.5 & - & - & - & - & - & - & - & - & - \\
\hline & 2 & 45.1 & 21.3 & 47.3 & 41.5 & 19.3 & 46.6 & 37.8 & 17.2 & 45.3 & 34.9 & 15.5 & 44.6 \\
\hline & 5 & 31.3 & 18.7 & 59.7 & 27.0 & 15.9 & 58.8 & 22.7 & 13.0 & 57.4 & 19.8 & 11.3 & 56.8 \\
\hline & 10 & 41.8 & 29.9 & 71.6 & 35.9 & 25.4 & 70.8 & 30.0 & 20.9 & 69.7 & 25.9 & 17.9 & 69.1 \\
\hline & 20 & 39.8 & 28.1 & 70.7 & 35.2 & 24.7 & 70.3 & 29.9 & 20.6 & 69.0 & 26.2 & 17.9 & 68.3 \\
\hline & 40 & 38.4 & 26.2 & 68.1 & 35.0 & 23.5 & 67.4 & 31.2 & 20.6 & 66.0 & 28.4 & 18.6 & 65.3 \\
\hline \multirow{6}{*}{$18^{\circ} \mathrm{C}$} & 1 & (133) & $(46.8)$ & $(35.2)$ & $(138)$ & $(49.6)$ & $(36.0)$ & - & - & - & - & - & - \\
\hline & 2 & 91.4 & 32.8 & 35.8 & 85.8 & 31.6 & 36.8 & 78.5 & 29.9 & 38.1 & 73.3 & 28.7 & 39.2 \\
\hline & 5 & 44.5 & 21.2 & 47.7 & 40.7 & 19.7 & 48.5 & 36.1 & 18.0 & 50.0 & 32.8 & 16.7 & 51.1 \\
\hline & 10 & 57.7 & 33.3 & 57.8 & 48.9 & 28.6 & 58.5 & 39.8 & 23.9 & 59.9 & 33.8 & 20.6 & 61.0 \\
\hline & 20 & 74.7 & 45.0 & 60.2 & 56.1 & 34.2 & 61.0 & 38.5 & 24.0 & 62.3 & 29.2 & 18.5 & 63.4 \\
\hline & 40 & 87.9 & 53.5 & 60.9 & 61.6 & 38.1 & 61.9 & 38.8 & 24.5 & 63.2 & 27.0 & 17.4 & 64.2 \\
\hline
\end{tabular}

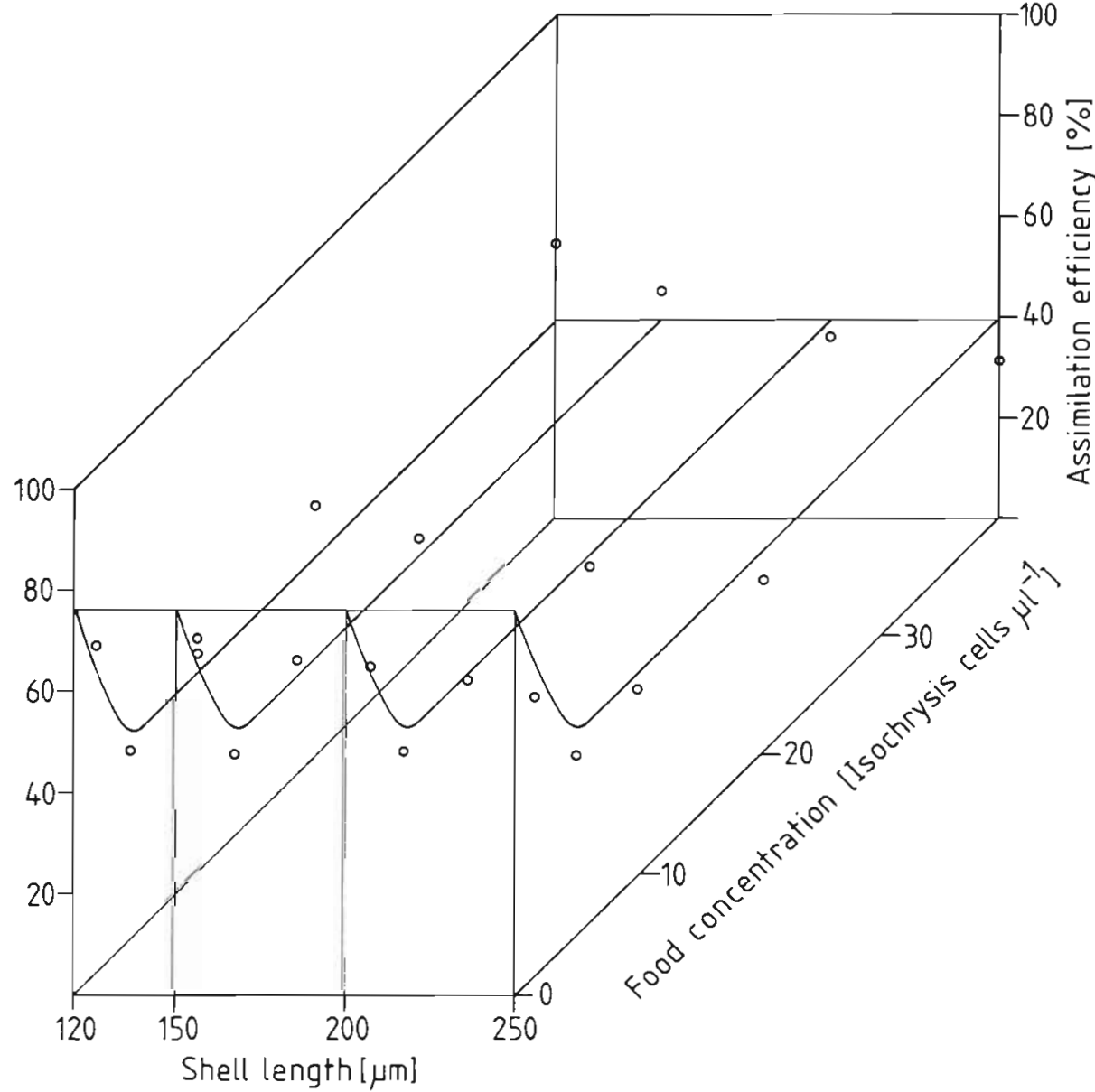

Fig. 2. Mytilus edulis, larvae. Assimilation efficiency $(\%)$ at various food concentrations and larval sizes; data from Table 2 (mean for the 3 experimental temperatures); curves fitted by eye (see also text) 
In experiments with oyster larvae, Walne (1965) could not correlate larval size and absorption efficiency. The same phenomenon has been reported with adult mussels by Vahl (1973). A correlation of this kind is not to be expected, because a change in assimilation and absorption efficiency should be concomitant with changes in morphology and/or physiology of the digestive tract. Consequently, the slightly increasing or decreasing trends found here must be regarded as being within the experimental error of the estimates.

Assimilation efficiency depends also on the food quantity. Richman (1958) observed a higher assimilation at low food concentrations with daphnids; so did Klekowski and Shushkina (1966) and Gaudy (1974) with the absorption efficiency of copepods. This phenomenon has also been found in these experiments (Fig. 1). According to descriptions with prosobranch larvae, it may be effected by an enhanced uptake of food particles into the digestive gland.

At food concentrations between 5 and 40 cells $\mu \mathrm{l}^{-1}$, assimilation efficiency was more or less identical. This is correlated with the fact that the ingestion capacity level has been attained within that range of food concentration (Sprung, 1984b). This is paralleled by a decrease in the filtration rate with increasing food concentration; e.g. Winter (1977) has pointed out this with respect to adult mussels. These facts have been considered when drawing Fig. 2.

Reviewing literature data, Welch (1968) found lower assimilation efficiencies with herbivores and detritivores compared with carnivorous species. Carnivorous species can in particular cases show assimilation efficiencies up to $98 \%$. This is in contrast to those observed with other herbivores and detritivores (Table 3; Conover, 1978). This makes sense from the ecological point of view, because detritus particles can be ingested several times.

\section{Gross growth efficiency $K_{1}$}

Data on gross growth efficiency have been discussed intensively in the context of fish rearing experiments. They provide an index for the quality of the food tested. With literature data, Paloheimo and Dickie (1966) have developed the 'K-line theory'. According to this, the logarithms of the $\mathrm{K}_{1}$-values should decrease linearly with the food quantity ingested. For adult
Fig. 3. Mytilus edulis, larvae. Gross growth efficiency $\mathrm{K}_{1}(\%)$ at various food concentrations and larval sizes: data points from Table 2 and maintenance rations from Sprung (1984d) pooled for the 3 experimental temperatures; curves fitted by eye (see also text)

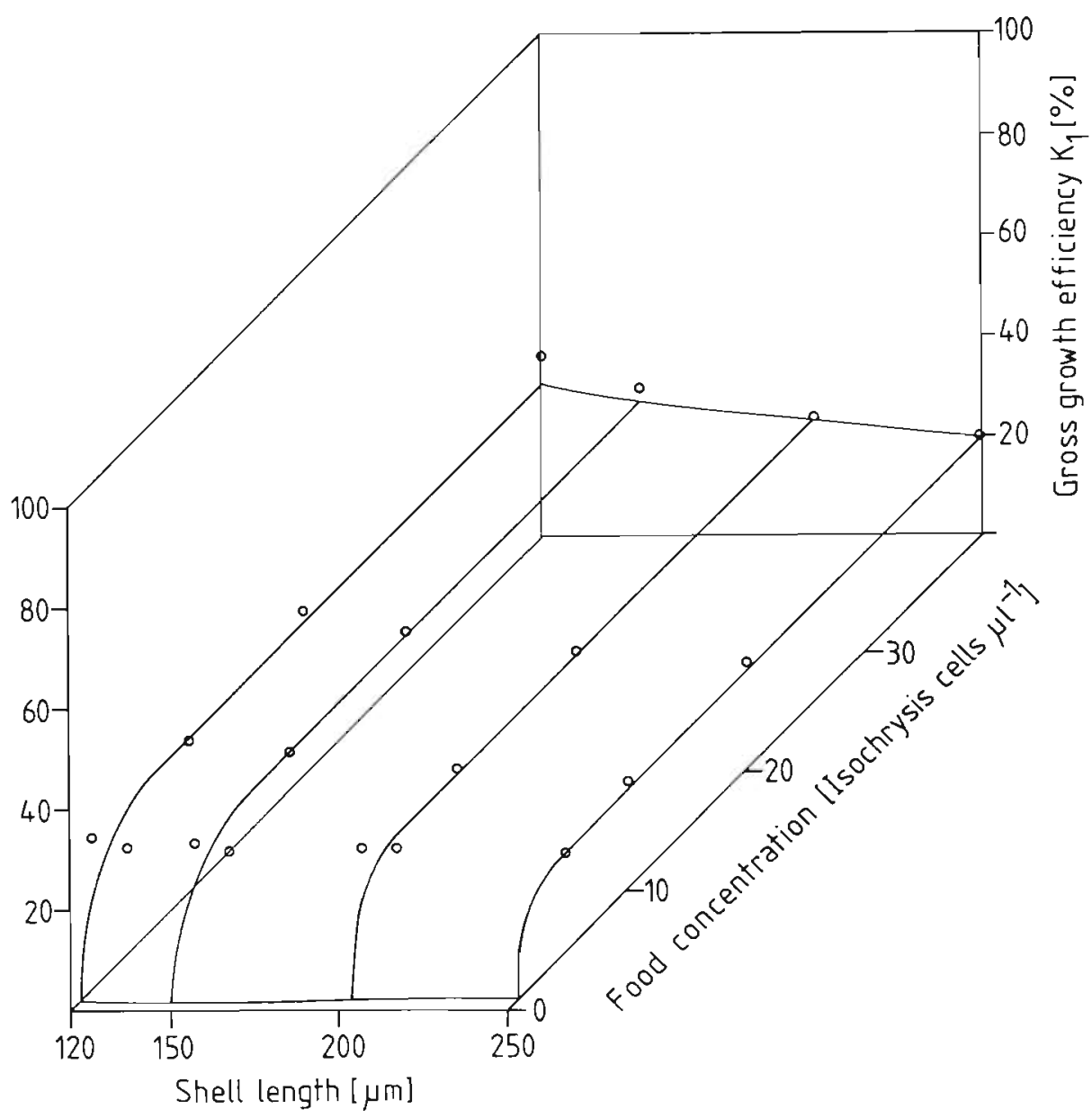


Table 3. Bivalyia, larvae. Literature data on assimilation and growth efficiencies

\begin{tabular}{|c|c|c|c|c|c|}
\hline Species & Food & $\begin{array}{l}\text { Assimilation } \\
\text { efficiency }\end{array}$ & $\begin{array}{l}\text { Gross growth } \\
\text { efficiency } K_{1}\end{array}$ & $\begin{array}{l}\text { Net growth } \\
\text { efficiency } \mathrm{K}_{2}\end{array}$ & Source \\
\hline Ostrea edulis & Isochrysis & $\cdot 13-45 \%$ & - & $75-80 \%$ & Walne (1965) \\
\hline Ostrea edulis & Isochrysis & $41-77 \%$ & - & $55-79 \%$ & Gabbott and Holland (1973) \\
\hline Ostrea edulis & $\begin{array}{l}\text { Isochrysis } \\
+ \text { Chaetoceros }\end{array}$ & $29-46 \%$ & $17-32 \%$ & $54-70 \%$ & Helm (in Bayne, 1984) \\
\hline Mytilus edulis & Natural food & - & - & $73 \% ; 60 \%$ & Jørgensen $(1952,1981)$ \\
\hline Mytilus edulis & $?$ & $71 \%$ & $65 \%$ & - & Bayne (1976) \\
\hline Mytilus edulis & $\begin{array}{l}\text { Isochrysis } \\
+ \text { Monochrysis }\end{array}$ & $33-44 \%$ & $19-26 \%$ & $60-73 \%$ & Jespersen and Olsen (1982) \\
\hline Mytilus edulis & Isochrysis & $20-50 \%$ & $25-40 \%$ & $60-70 \%$ & This paper \\
\hline
\end{tabular}

mussels, Thompson and Bayne (1974) have calculated K-lines. They show this decrease with the food concentration.

For mussel larvae, evidence for this decrease of $\mathrm{K}_{1}$ values within the range of food concentrations tested could not be provided. The 'K-lines' drawn in Fig. 3 are thus based on the mean of all $K_{1}$-values estimated at the three temperatures for a distinct larval size. Gross growth efficiency as well as net growth efficiency equals zero at the maintenance food concentration. This line has been included in Fig. 3 and 4 according to data from Sprung (1984d).

It is to be expected that gross growth efficiency has lower values with larger animals (Bayne et al., 1976). A decrease in $K_{1}$-values has only been observed with the 12 and $18{ }^{\circ} \mathrm{C}$-experiments. Nevertheless this trend is

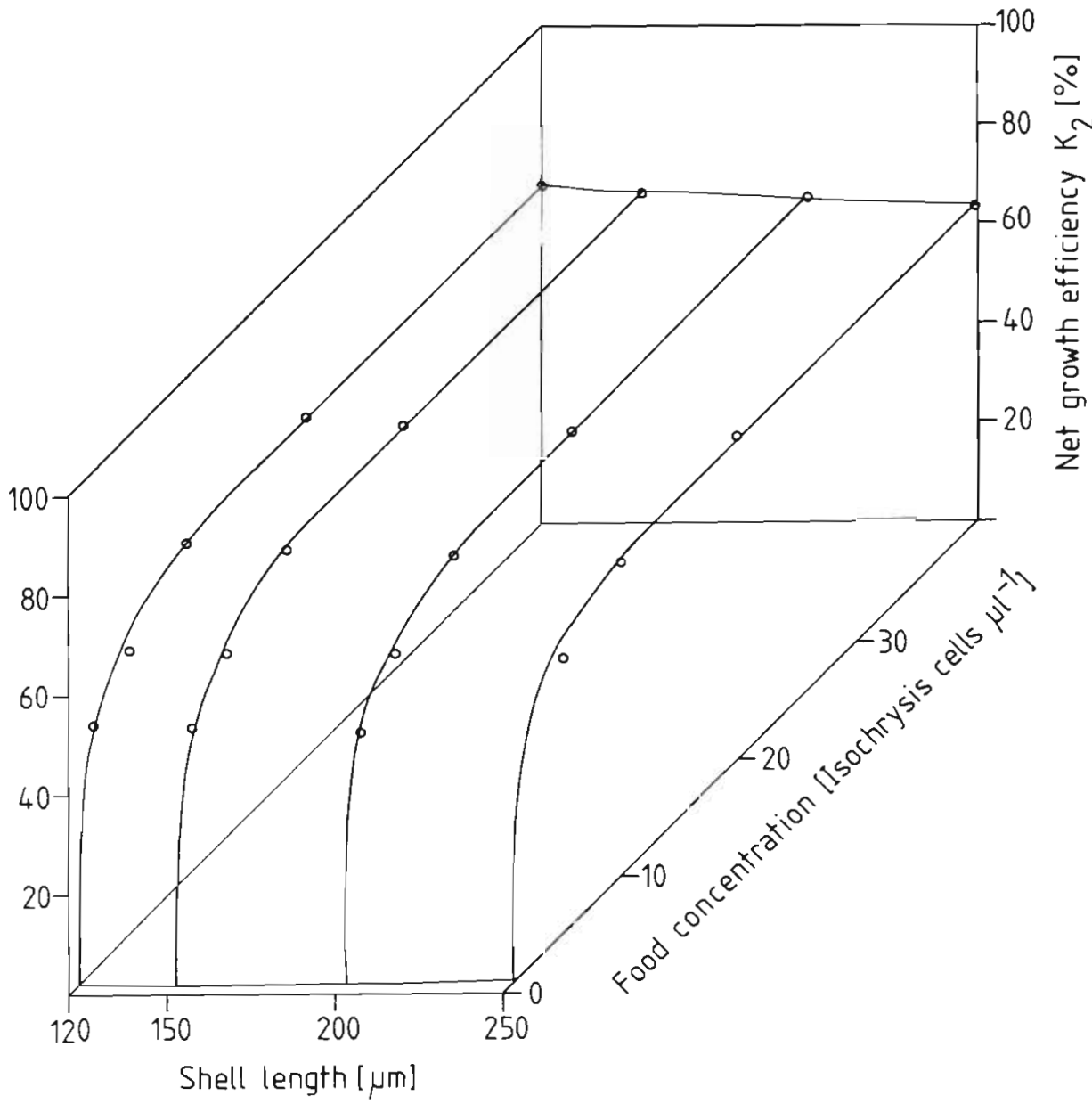

Fig. 4. Mytilus edulis, larvae. Net growth efficiency $K_{2}(\%)$ at various food concentrations and larval sizes; data points from Table 2 and maintenance rations from Sprung (1984d) pooled for the 3 experimental temperatures; curves fitted by eye (see also text) 
reflected by the mean over all temperature levels tested. Allowance for this has been made in Fig. 3.

$\mathrm{K}_{1}$-values of aquatic organisms have been reviewed by Welch (1968) and by Corner and Davies (1971). They range rather homogeneously between 15 and $35 \%$ of the ingested ration. This can also be confirmed by my own and literature data of bivalve larvae (except that of Bayne, 1976; Table 3).

\section{Net growth efficiency $K_{2}$}

According to my experimental data, net growth efficiencies increase from the maintenance concentration to its maximum values at about 10 cells $\mu \mathrm{l}^{-1}$ (Fig. 4). Richman (1958) reported a similar effect with daphnids.

A decrease with larval size $\left(6\right.$ and $12^{\circ} \mathrm{C}$-values) could not be found in the $18^{\circ} \mathrm{C}$-experiments and also not by Helm (in Bayne, 1984) with oyster larvae. According to the allometry of physiological processes during growth (e.g. Bayne et al., 1976), however, $\mathrm{K}_{2}{ }^{-}$ values must decrease regarding the whole life cycle. This has already been pointed out by Jørgensen (1952). Consequently, larvae have higher net growth efficiencies than the adult animals (Holland, 1978).

Indeed, reviewing several papers, Riisgård and Randløv (1981) have quoted values between 26 and $61 \%$ for adult mussels in contrast to $60-70 \%$ for its larvae recorded here.

Mortality is known to decrease with body size. Thus, high $\mathrm{K}_{2}$-values must also be looked upon as an adaptive response to environmental conditions. Also compared with many holoplanktonic animals, meroplanktonic organisms have higher $\mathrm{K}_{2}$-values (60 to $70 \%$ in contrast to 10 to $40 \%$; Holland, 1978).

Welch (1968) has pointed out that assimilation efficiency and net growth efficiency are negatively correlated in aquatic organisms. He interprets this correlation with the fact that suspension feeders (with low assimilation efficiencies) spend only a small part of their metabolic energy to obtain their food, in contrast to predators. They are thus in the position to convert more energy to growth. This trend can be confirmed by my experimental data.

Acknowledgements. This paper is a contribution to research project 'Experimentelle Marine Okosystemanalyse' sponsored by Bundesministerium für Forschung und Technologie, Bonn (Grant No. MFU-0328/1). It is based on parts of the author's doctoral thesis submitted to Kiel University. I am grateful to Professor Dr. W. Noodt for supervising the thesis, to Dr. K. Anger for helpful discussions of this paper, to Dr. E. Hagmeier for providing the algal cultures for the experiments, and to Dr. M. Rieper for correcting the manuscript. I am also indebted to Studienstiftung des Deutschen Volkes, Bonn-Bad Godesberg for financial support.

\section{LITERATURE CITED}

Bayne, B. L. (1976). The biology of mussel larvae. In: Bayne, B. L. (ed.) Marine mussels: their ecology and physiology. Cambridge University Press, London, p. 81-120

Bayne, B. L., Thompson, R. J., Widdows, J. (1976). Physiology. In: Bayne, B. L. (ed.) Marine mussels: their ecology and physiology. Cambridge University Press, London, p. $121-260$

Bayne, B. L. (1984). The physiological ecology of marine molluscan larvae. In: Gray, J. S., Christiansen, M. E. (ed.) Eighteenth European Marine Biology Symposium, Oslo. Wiley, Chichester (in press)

Conover, R. J. (1966). Assimilation of organic matter by zooplankton. Limnol. Oceanogr. 11: 338-345

Conover, R. J. (1978). Transformation of organic matter. In: Kinne, O. (ed.) Marine ecology, Vol. IV, Dynamics. Wiley, Chichester, p. 221-499

Corner, E. D. S., Davies, A. G. (1971). Plankton as a factor in the nitrogen and phosphorus cycles in the sea. Adv. mar. Biol. 9: 101-204

Crisp, D. J. (1971). Energy flow measurements. In: Holme, N. A., McIntyre, A. D. (ed.) Methods for the study of marine benthos. Blackwell, Oxford, p. 197-279

Gabbott, P. A., Holland, D. L. (1973). Growth and metabolism of Ostrea edulis larvae. Nature, Lond. 241: 475-476

Gaudy, R. (1974). Feeding of four species of pelagic copepods under experimental conditions. Mar. Biol. 25: 125-141

Holland, D. L. (1978). Lipid reserves and energy metabolism in the larvae of benthic marine invertebrates. In: Malins, D. C., Sargent, J. R. (ed.) Biochemical and biophysical perspectives in marine biology, Vol. IV. Academic Press, New York, p. 85-123

Jespersen, H., Olsen, K. (1982). Bioenergetics in veliger larvae of Mytilus edulis L. Ophelia 21: 101-113

Jørgensen, C. B. (1952). Efficiency of growth in Mytilus edulis and two gastropod veligers. Nature, Lond 170: 714

Jargensen, C. B. (1981). Mortality, growth and grazing impact of a cohort of bivalve larvae, Mytilus edulis. Ophelia 20: 185-192

Jorgensen, C. B. (1983). Ecological physiology; background and perspectives. Comp. Biochem. Physiol. 75A: 5-8

Klekowski, R. Z., Shushkina, E. A. (1966). Ernährung, Atmung, Wachstum und Energieumformung in Macrocyclops albidus (Jurine). Verh. int. Ver. Limnol. 16: 399-418

Paloheimo, J. E., Dickie, L. M. (1966). Food and growth of fishes. III. Relations among food, body size, and growth efficiencies. J. Fish. Res. Bd Can. 23: 1209-1248

Richman, S. (1958). The transformation of energy by Daphnia pulex. Ecol. Monogr. 28: 273-291

Riisgård, H. U., Randløv, A. (1981). Energy budgets, growth and filtration rates in Mytilus edulis at different algal concentrations. Mar. Biol. 61: 227-234

Sprung, M. (1984a). Physiological energetics of mussel larvae (Mytilus edulis). I. Shell growth and biomass. Mar. Ecol. Prog. Ser. 17: 283-293

Sprung, M. (1984b). Physiological energetics of mussel larvae (Mytilus edulis). II. Food uptake. Mar. Ecol. Prog. Ser. 17: 295-303

Sprung, M. (1984c). Physiological energetics of mussel larvae (Mytilus edulis). III. Respiration. Mar. Ecol. Prog. Ser. 18: $171-178$

Sprung, M. (1984d). Experiments on nutritional stress on the larvae of the mussel Mytilus edulis L. In: Verdonk, N. H. van den Biggelaar, J. A. M., Tompa, A. (ed.) The Mollusca, Vol. III. Development. Academic Press, New York, p. 299-343 
Thompson, R. J., Bayne, B. L. (1974). Some relationships between growth, metabolism and food in the mussel Mytilus edulis. Mar. Biol. 27: 317-326

Vahl, O. (1973). Pumping and oxygen consumption rates of Mytilus edulis L. of different sizes. Ophelia 12: 45-51

Walne, P. R. (1965). Observations on the influence of food supply and temperature on the feeding and growth of the larvae of Ostrea edulis. Fishery Invest, Lond. II 24: 1-45 Welch, H. E. (1968). Relationships between assimilation efficiencies and growth efficiencies for aquatic consurners. Ecology 49: 755-759

Winter, J. E. (1977). Suspension-feeding in lamellibranchiate bivalves, with particular reference to aquaculture. Medio Ambiente 3: 48-69

This paper was presented by Professor H.-P. Bulnheim; it was accepted for printing on March 17, 1984 